\title{
TRANSCRIAÇÃO DE LOVECRAFT: UMA TRADUÇÃO DO CONTO THE FESTIVAL
}

\section{THE TRANSCREATION OF LOVECRAFT: A TRANSLATION OF THE SHORT STORY THE FESTIVAL}

\author{
Ágeson Christian da Silva* \\ Rafael Alexandre Gomes dos Prazeres**
}

Resumo: O presente trabalho se insere no campo da tradução literária, tendo como objetivo traduzir para o português o conto The Festival (1925) do escritor estadunidense Howard Phillips Lovecraft. Para realizar a tarefa, utilizamos o processo tradutório da transcriação, desenvolvida pelo poeta e tradutor brasileiro Haroldo de Campos. Além de Campos (2015a, 2015b, 2015c, 2015d), valemo-nos também das contribuições de Walter Benjamin (2008), Roman Jakobson (1975), Célia Magalhães (1998), dentre outros. E, como suporte literário, fizemos uso de Lovecraft (2011). Os resultados da tradução indicam que a transcriação apresentou soluções adequadas para recriação da atmosfera de estranheza e horror da poética horripilante de Lovecraft.

Palavras-chave: H.P. Lovecraft; Haroldo de Campos; Transcriação.

ABstract: The current paper is a literary translation of the short story The Festival by North-American writer H.P. Lovecraft. The main objective was to transcreate the story from English to Portuguese, using the transcreation, a translation process developed by the Brazilian poet and translator Haroldo de Campos. Besides Campos (2015a, 2015b, 2015C, 2015d), the publications of Walter Benjamin (2008), Roman Jakobson (1975), Célia Magalhães (1998), among others, were used to write this work. The book Lovecraft: Complete Fiction (2011) was used as a literary support. The results of the translation denote that the selected process provided appropriate solutions for the recreation of the weird atmosphere and the horrific poetic of Lovecraft.

KEYwords: H.P. Lovecraft; Haroldo de Campos; Transcreation.

\footnotetext{
"Graduado em Letras/Inglês pela Universidade do Estado da Bahia (UNEB) - Campus X (Teixeira de Freitas) - e Professor da Secretaria Estadual da Educação do Estado da Bahia. E-mail: ageson.christian@gmail.com.

** Mestre em Letras pela Universidade Federal do Espírito Santo (UFES), Doutorando em Estudos Literários pela Universidade Federal de Minas Gerais (UFMG) e Professor da Universidade Federal do Sul da Bahia (UFSB). E-mail: rafaeldosprazeres@ufsb.edu.br.
} 


\section{INTRODUÇÃo}

Howard Phillips Lovecraft desenvolveu um estilo peculiar de escrita. Unindo prosa e poesia, ciência e magia, antiguidade clássica e ficção científica, o escritor estadunidense conseguiu tecer contos fantásticos horrendos. Além do entrelaçamento de temas distintos, uma característica marcante da obra de Lovecraft é a escolha minuciosa de palavras compatíveis com os temas em si. Por isso, selecionamos um processo de tradução capaz de dar suporte a todo o esforço poético necessário para traduzir a prosa de Lovecraft: a transcriação de Haroldo de Campos. Tal processo foi pensado originalmente para solucionar os problemas da tradução de textos poéticos em versos, porém, neste trabalho, testamos a sua efetividade em relação à escrita em prosa.

É importante, de antemão, informar que este trabalho não tem como coluna de sustento a apresentação de secções comentadas de uma ou outra escolha vocabular de nossa prática tradutória, embora algumas delas surjam como curiosidades e exemplos ao longo da última seção. Acreditamos que as análises tradutórias com base em comentários de seleções linguísticas e resoluções de termos compõem um lugar de extrema importância nos estudos e nas práticas da tradução. Com isso, não nos furtamos a fazê-las nos espaços adequados. Contudo, nosso propósito exclusivo aqui é ofertar à audiência uma transcriação do conto "The Festival" de H.P. Lovecraft, traduzido apenas uma vez para a língua portuguesa, em 2016, pelo quarteto formado por Alda Porto, Vilma Maria da Silva, Lenita Rimoli Esteves e Paulo Cezar Castanheira. A plataforma disponível para a extensão deste trabalho poderia suportar outros gêneros textuais, tais como: artigo, ensaio, depoimento, resenha, dentre outros. Entre análise e comparação, entre comentários e desenvolvimento teórico ou mesmo para apresentar resultados de pesquisa. No entanto, selecionamos a tradução criativa do conto como principal gênero e elemento de verificação. E, como um ato de transcriação de prosa-atitude exercitada com menor ocorrência, em comparação à transcriação de versos -, julgamos ser relevante apresentar, nas extremidades do resultado da tradução (entremeio), uma contextualização do processo tradutório (acima) e um pequeno recorrido histórico sobre a obra (abaixo).

O conto escolhido para a tradução neste artigo foi “The Festival”, publicado em 1925 na revista Weird Tales. O conto faz parte do Cthulhu Mythos, uma série de contos que, interligados, formam a história mais famosa de Lovecraft, a história do despertar do Deus Antigo Cthulhu. Em "The Festival", o passado do protagonista é desconhecido, enquanto seu futuro aparece momentaneamente apenas para marcar a loucura resultante do festival macabro que é observado por ele. No conto, o personagem principal guia o leitor por um evento sobrenatural, o ritual macabro realizado nos subterrâneos da fictícia cidade costeira de Kingsport. Similar a outros contos de Lovecraft, "The Festival" possui extensas descrições de cenários e curtos diálogos indiretos. 
A fim de nos deter a essa leitura de forma crítica e criativa, tomamos como ponto de partida a transcriação. Seguindo o pensamento de Haroldo de Campos (2015), para "transcriar" uma obra de arte verbal, é preciso dissecá-la, analisando cada parte constituinte, entendendo como ela funciona. Portanto, é preciso desmontar o conto, observar individualmente cada um de seus atributos e enxergar todas as suas conexões, para então poder remontá-lo na tradução. A fim de dar conta da tarefa fundamental deste trabalho que é a tradução e de apresentar, aqui ou acolá, algumas de nossas escolhas no formato e na extensão sugeridas aqui, optamos por dividi-lo em três etapas, a saber: a) apresentar o contexto da transcriação; b) oferecer o resultado de nossa tradução do conto, em formato integral; e c) Dispor alguns comentários relacionados a algumas de nossas escolhas no ato tradutório.

\section{Transcriação}

A tradução é um termo polissêmico que, como aponta José Pinheiro de Souza (1998), pode significar o texto traduzido, o ato de traduzir ou a disciplina que estuda essa atividade. Além disso, Souza (1998) explica que a tradução não possui uma teoria unificadora, existindo assim diversos procedimentos de tradução em relação à sua conceituação, os principais deles são a tradução literal e a tradução livre. O primeiro se refere ao ato de traduzir como transferência rigorosa de significado de um código para outro, já o segundo procedimento, a tradução livre, se atém à subjetividade e criatividade das palavras.

Tendo em mente a multiplicidade de interpretações do leitor-tradutor e de sua influência na significação do texto, surgiria a dúvida: seria a tradução do texto literário impossível? Em seu artigo “Teorias da Tradução: uma visão integrada”, Souza (1998) demonstra que alguns autores citados no referido artigo, como Antoine Meillet e José Paulo Paes, defendem a impossibilidade da tradução, principalmente da tradução de textos literários. De acordo com essa perspectiva, o ato de traduzir textos que possuem uma carga semântica múltipla seria impossível, pois cada língua define o modo como seus falantes percebem o mundo e cada novo leitor-tradutor imporia a sua visão de mundo e sua interpretação do texto em suas traduções. Mantendo a ideia da impossibilidade da tradução de textos literários, em especial dos textos em versos, o linguista russo Roman Jakobson (1975) afirma que a forma do texto (a morfologia, a sintaxe, os fonemas, por exemplo) tem uma significação própria e não poderia ser traduzida sob a perspectiva da tradução livre. Com isso, o autor classifica três tipos de tradução: a tradução intralingual, interlingual e intersemiótica. A tradução intralingual consiste na "reformulação" dos signos verbais em uma mesma língua (JAKOBSON, 1975, p. 64). Por exemplo, em "The Festival”, Lovecraft faz uso das palavras endless (LOVECRAFT, 2011, p. 262) e ceaseless (LOVECRAFT, 2011, p. 263), ambas com significado similar ('algo que não termina', 'infinito'), mas que possuem signos verbais distintos dentro de uma mesma língua. A tradução interlingual é a "tradução propriamente dita", a interpretação dos signos verbais em outra 
língua (JAKOBSON, 1975, p. 65). Por exemplo, é quando o tradutor escolhe uma palavra como "infindo", na língua portuguesa, para interpretar o signo endless da língua inglesa. A tradução intersemiótica diz respeito à transformação de signos verbais para um sistema de signos não verbais. Como exemplo, pode-se observar a adaptação publicada em 2014 do conto "The Picture in the House" de Lovecraft em HQ quando Steven Jones (texto) e Rob Davis (ilustração) verteram em quadrinhos e balóes - para signos verbais e não-verbais - todo o conto de Lovecraft.

Tendo em mente essas definições de Jakobson (1975, p. 64-65), é possível afirmar que toda manifestação linguística é em si uma tradução. Portanto, toda experiência cognitiva pode ser traduzida para qualquer sistema linguístico. O linguista russo resolveria então o problema das correspondências de palavras entre línguas, porque, se cada signo é uma representação de uma experiência cognitiva, para traduzi-lo de uma língua para outra, o/a tradutor/a precisaria ter em mente a mesma "atmosfera" apresentada pelo texto de partida. Dentre os diversos tradutores que tentaram refutar a intraduzibilidade de textos poéticos, destaca-se o tradutor paulistano Haroldo de Campos.

Cunhada por Campos, a prática da transcriação surge como um modo de "recriação do texto original na língua de chegada, ou seja, explorar os recursos articulados na língua de partida e reproduzi-los analogamente na língua de chegada" (GESSNER, 2016, p. 144). O poeta se baseou em alguns poetas, tradutores, filósofos e linguistas de sua época, dentre eles Ezra Pound, Walter Benjamin, Albrecht Fabri, Paulo Rónai e Max Bense, para embasar um método tradutório que levasse em consideração não apenas o conteúdo semântico como alicerce do ato de traduzir, mas também toda a informação estética, histórica, cultural e o efeito que uma obra de arte verbal carrega em si. Em seu texto "Da tradução como criação e crítica", publicado primeiramente na revista Tempo Brasileiro em 1963 e incluído por Marcelo Tápia e Thelma Nóbrega no livro Haroldo de Campos: Transcriação, Campos (2015a) apresenta a noção de tradução como criação. De acordo com seu desenvolvimento conceitual, além da criação, a tradução deve se preocupar igualmente com a estética e com a significação.

Uma tese que sustenta boa parte das ideias de Campos é a da tradução como crítica, de Ezra Pound. Para Pound (1968), a tradução como crítica objetiva eliminar repetições, pois traduz-se o que é relevante. Isso permite às atuais e futuras gerações de leitores e escritores encontrar mais facilmente a literatura substancial - aquela que ultrapassa particularidades, tem potencial de atingir qualquer leitor, em qualquer espaço e tempo. Isso ocorre porque o tradutor, ao selecionar a obra a ser traduzida como recriação, aumenta a diversidade do que está escrito em sua língua e permite que novos leitores estabeleçam contato com obras literárias pouco conhecidas e/ou estudadas dentro do âmbito literário e acadêmico aos quais estão inseridos. O tradutor deve encontrar a relevância universal do texto de partida e ser capaz de "transcriá-lo" na língua de chegada.

Em seu artigo "Tradução e Transculturação: A teoria monstruosa de Haroldo de Campos", Célia Magalhães (1998) compara a transcriação de Campos com o monstro de 
Frankenstein de Mary Shelley, ambos criados a partir de pedaços de outras criaturas ou - no caso da prática de Campos - de recortes de outras teorias da tradução. Além da abordagem apontada por Magalhães (1998) e da já citada tradução crítica de Ezra Pound (1968), ao longo do desenvolvimento do seu método tradutório, Campos também tomou como base para sua criação a contribuição descrita pelo filósofo alemão Walter Benjamin, presente no ensaio "A tarefa do tradutor", de 1921, em que o filósofo apresenta a necessidade da busca eterna da "língua pura" na sua alta relação entre línguas e entre a obra de arte verbal como intencionalidade, constituindo-se como pontos cruciais no ato da tradução.

No caminho da costura entre tecidos (Frankenstein) teóricos da tradução, com os quais Haroldo de Campos coseu a transcriação e pensando, ainda, nas definições de Jakobson (1975) que indicariam a traduzibilidade de qualquer experiência cognitiva, é possível chegar à conclusão de que todas as línguas partiriam de um ponto em comum, o pensamento abstrato, puro. Segundo Benjamin (2008), durante o ato de traduzir, o tradutor-autor, visando recriar na língua de chegada a substância do texto originário, livra-se do que é superficial, deixando transparecer a afinidade entre as línguas, aproximando o texto da língua pura. Isto é, para se atingir a língua pura e para realizar a tradução como "transcriação", o tradutor deve "desmontar" (CAMPOS, 2015a, p. 14) e vivissectar "as entranhas" do texto originário, a fim de remontá-lo em um corpo linguístico distinto. Consoante o filósofo alemão:

Como os cacos de uma ânfora, para que, nos mínimos detalhes, se possam recompor, mas nem por isso se assemelhar, assim também a tradução, ao invés de se fazer semelhante ao sentido do original, deve, em um movimento amoroso que chega ao nível do detalhe, fazer passar em sua própria língua o modo de significar do original (BENJAMIN, 2008, p. 61).

Esse "modo de significar" sobre o qual Benjamin teceu seu comentário acerca da tradução exige do tradutor uma profunda pesquisa vocabular em torno do texto fonte. Mas, também, é exigida uma pesquisa das características do autor, do período histórico de inscrição da obra, das seleções e experiências que formaram o texto e que se apresentam em outros textos paralelos da autoria. Só após essa árdua pesquisa, deve-se realizar o "movimento amoroso" de criar na língua de chegada o tal modo de significar.

Para demonstrar como as concepções de Benjamin sobre a língua pura e a intenção da obra se aplicam à teoria da "transcriação", Campos (2015b), em seu texto "Tradução e reconfiguração: o tradutor como transfingidor", utiliza o amparo teórico de Wolfgang Iser, Charles Peirce e Max Bense para consolidar a informação de que o texto de ficção é um signo que pode ser representado pelo trinômio semiótico Signo-Objeto-Interpretante. O autor também se apropria das definições de Iser sobre a relação triádica existente entre o real, o fictício e o imaginário para explicar que: 
O "texto fictício" é um "signo" (ou, mais exatamente, um "macrossigno", um ícone de relações). Como tal, pode ser representado por um triângulo, no qual um dos ângulos corresponde à "referência de realidade" (objeto, representação, ou dimensão semântica); o outro, à "referência do imaginário" (interpretante, expressão ou dimensão pragmática); no vértice do triângulo está o "ato de fingir", visto como "referência de meio" (linguagem, dimensão sintática), onde o fictício se apresenta como "figura de trânsito (Übergangsgestalt) entre o real e o imaginário" e o relacionamento, como "produto do ato de fingir", vem a ser a "configuração concreta de um imaginário" (CAMPOS, 2015b, p. 121).

Assim, quando o indivíduo fala, a sua mensagem é uma transgressão da realidade, uma referência ao objeto. Através do texto literário, isto é, do ato de fingir, a realidade é transformada em ficção, ao passo que esta ficção é realizada dentro do imaginário do receptor. Com o auxílio das definições de Iser, o autor explica que, dentro da realidade, estão todos os elementos extratextuais, o campo das referências às quais o texto diz respeito, enquanto os elementos intratextuais estão incluídos no ato de fingimento. Campos (2015b) expõe ainda que, na perspectiva da tradução como "transcriação", o tradutor "transcria" os elementos extratextuais ao inserir o texto em outro momento histórico, social e cultural, apresentando outro campo de referência aos receptores. Transcria, com isso, os componentes intratextuais ao recriar o texto em outro sistema linguístico e reconfigura o imaginário do texto de partida ao apresentá-lo a outros receptores ou por ser uma tradução. Ele esclarece que "o texto traduzido, como um todo (como um ícone de relações intra-e-extratextuais), não denota, mas conota seu original" (CAMPOS, 2015b, p. 124). Portanto, o tradutor "transcriador" transfinge a realidade para torná-la real dentro de outro imaginário. O poeta tradutor conclui: "Se o poeta é um fingidor, como queria Fernando Pessoa, o tradutor é um transfingidor" (CAMPOS, 2015b, p. 125).

Assim, Campos (2015b) explica que, ao traduzir sob a perspectiva transcriadora ou recriação paramórfica, o tradutor, chamado por ele de "leitor-autor", deve buscar a recriação não apenas dos elementos intratextuais, mas também dos extratextuais. Para Paulo Rónai (1976), o leitor-autor - que, a traduzir, pratica a forma mais atenta de leitura - deve primeiro desmontar o texto de partida, buscando conhecer cada átomo constituinte do corpo do texto originário. É importante apontar que um texto não existe no vazio, ele está inserido em um momento histórico e possui marcas tanto da linguagem corrente de sua época, quanto das construções sociais que formaram o imaginário do seu autor. Logo, percebendo o tradutor como leitor-autor e sabendo que a compreensão do leitor influencia na significação do texto, entendemos que toda nova leitura, e assim toda nova tradução, seria uma versão renovada do texto. Por isso, para Campos (2015c), o tradutor deve manter-se consciente da transposição dos elementos extratextuais do texto originário para sua tradução. 
Haroldo de Campos se assemelha ao monstro de Frankenstein, como comparou Magalhães (1998), também por ser um traidor que se rebela e renuncia a posição de servo. Haroldo trai, em primeiro lugar, a tradução subserviente. Em seu texto "Da Transcriação: Poética e Semiótica da Operação Tradutora”, Campos (2015d) admite ter criado neologismos como "transtextualização" e "transluciferação" para afastar-se do conceito naturalizado de tradução. Magalhães (1998) afirma, ainda, que a rebeldia de Campos também pode ser notada quando o tradutor se coloca como autor da obra traduzida (modificando seu título, colocando prefácios, posfácios e notas de rodapé nas obras que traduz para se manter presente, sempre à vista do leitor).

Se levarmos em consideração todas essas diferentes perspectivas sobre o ato de traduzir e de criar, poderíamos afirmar que "transcriação" é uma forma de tradução que visa criar um texto - paralelo ao texto de partida - ao mesmo tempo em que o autor se esforça para transpor todos os seus elementos intra e extratextuais. Essa tradução seria em si um ato crítico, pois através dela o texto selecionado permaneceria vivo em outra língua e cultura, isto é, a vivacidade do texto seria o resultado da presença reflexiva do autor ao recriar os elementos constituintes da obra de partida. Além disso, aquilo que foi dito (ou escrito) na língua de partida não seria simplesmente repetido na língua de chegada. As informações íntimas, ou essenciais, como sugeriu Benjamin (2008), prevaleceriam no texto traduzido, porém o campo de referências e o corpo físico do texto seriam transformados. Em seu posfácio ao livro Haroldo de Campos: Transcriação, Marcelo Tápia (2015) compara o tradutor a um vampiro. Utilizando as metáforas criadas por Campos no ensaio “Transluciferação Mefistofáustica” sobre a tradução como transfusão de sangue, Tápia (2015) afirma que o tradutor sugaria o sangue do texto de partida, revitalizando-se, vivissectaria o corpo linguístico, realizando uma refeição sacrificatória. Ainda com o autor, Haroldo de Campos adota a mesma atitude de Oswald de Andrade em seu Manifesto Antropofágico, ao devorar o texto de partida para transcriá-lo, visando tornar seu aquilo que não o é de princípio.

Dito isso, observemos, a seguir, nossa transcriação do conto de Lovecraft - objeto principal deste trabalho -, tomado o ambiente prosaico como exercício de materialização da transcriação. Afinal, conforme Campos, "A tradução de poesia (ou prosa que a ela equivalha em problematicidade) é antes de tudo vivência interior do mundo e da técnica do traduzido" (CAMPOS, 2015a, p. 14). 


\section{THe FestivaL}

\section{O Festival}

"Efficiunt Daemones, ut quae non sunt, sic tamen quasi sint, conspicienda hominibus exhibeant"

- Lactantius

Eu estava longe de casa, e a magia do mar do leste estava sobre mim. Ao entardecer, ouvi pancadas nas rochas e tive a certeza de que ela jazia do outro lado daquela colina onde os retorcidos salgueiros se contorciam contra o céu desanuviado e contra as primeiras estrelas do anoitecer. E porque meus ancestrais haviam me invocado para a velha cidade além, eu me arrastei pela neve rasa, recém-caída na estrada que subia solitária até o ponto em que Aldebaran tremeluzia por entre as árvores, em direção à macróbia cidade que eu jamais avistara, mas com a qual sempre sonhara.

Estava na época do Yuletide, que os homens chamam de Natal apesar de saberem em seus corações que é mais velho do que Belém e a Babilônia, mais antigo que Memphis e a humanidade. Estava na época do Yuletide e eu estava finalmente indo à macróbia cidade costeira onde meu povo havia residido e mantido o festival no inveterado tempo em que era proibido; onde também ordenaram a seus filhos e a suas filhas a realizarem o festival uma vez a cada cem anos, para que a recordação dos segredos primevos não fosse esquecida. O meu era um povo antigo, já era antigo mesmo quando essa terra foi colonizada há trezentos anos. Eles eram excêntricos porque haviam chegado ali como um povo caliginoso, prófugo dos jardins austrais opiáceos de orquídea e falavam em outra língua antes de aprenderem a língua dos pescadores de olhos cerúleos. E agora estavam espalhados e compartilhavam apenas os rituais arcanos que nenhum vivente poderia compreender. Eu era a única que voltava naquela noite para a cidade macróbia como foi profetizado nas lendas, pois apenas aqueles desafortunados e desolados se recordam.

Então, para além da cúspide da colina, avistei Kingsport se desnovelar enregelada sob o crepúsculo, esbranquiçada pela neve; Kingsport com suas grimpas e campanários vetustos, suas casas com telhado triangular e topos de chaminé, seu cais e suas pequenas pontes, seus salgueiros e seus cemitérios; dédalos infindos de ruas tortuosas, estreitas, abruptas, e uma vertiginosa cimeira coroada por uma igreja, a qual o tempo não ousou tocar; meada infindável de casas coloniais empilhadas e derramadas em todos os ângulos e níveis, como se atingidas pela entropia das brincadeiras infantis; antiguidade pairando em asas acinzentadas sobre os inverno-níveos telhados empenados e semioctogonais; uma por uma, lucarnas e janelas 
envidraçadas, cintilando no frio anoitecer e se juntando a Órion e às estrelas arcaicas. ${ }^{1} \mathrm{E}$ contra o cais putrescente o mar se atirava; o mar recôndito, imemorial, do qual o povo saiu em tempos longínquos.

Ao lado da estrada, por sobre a cimeira, uma sumidade ainda maior se levantava, andurrial e moldada pelo vento. Notei que era um campo profano onde lápides negras brotavam morbosamente da neve, como unhas putrefatas de um cadáver gigantesco. A estrada sem rastros estava solitária. Por vezes, pensei ter ouvido um rangido remoto, horrendo, como um cadafalso tocado pelo vento. Haviam enforcado quatro das minhas ancestrais por bruxaria em 1692, mas eu não sabia exatamente onde.

Enquanto a estrada serpenteava pelo declive em direção ao mar, dei ouvidos em busca dos típicos sons alegres de um vilarejo ao anoitecer, mas não os escutei. Então lembrei-me da sazão, desconfiei que esses antigos povos Puritanos talvez tivessem costumes natalinos estranhos para mim, cheios de orações silenciosas ao redor da lareira. Assim, depois disso, não procurei mais por folguedos e viajantes, apenas segui adiante, passando pelas quintas aquietadas e iluminadas, pelos umbrosos muros de pedra, até avistar as tabuletas de velhos bazares e de tavernas do mar que rangiam com a brisa salina, e as aldravas grotescas de portas entre pilares refletindo a pouca luz proveniente das janelas acortinadas que preenchiam a ruela desnuda e deserta.

Eu havia consultado mapas da cidade, sabia onde encontrar a casa do meu povo. Fora dito que eu devia ser conhecida e bem recebida, pois longínquas lendas prevalecem em lugares solitários. Então me apressei pela Rua Dorso até o Pátio Circular, atravessando a neve recémcaída na única parte totalmente calçada da cidade, até onde a Ruela Verde dava lugar aos fundos do Empório. Os velhos mapas ainda eram precisos e eu não tive problemas, apesar de terem me dito em Arkham que pela cidade circulava um bondinho, devem ter mentido, pois não vi fio algum passar sobre minha cabeça. De qualquer forma, a neve teria escondido os trilhos. Estava satisfeita por ter preferido andar, pois o vilarejo esbranquiçado parecera venusto ${ }^{2}$ do alto da colina, e agora estava ansiosa para bater à porta do meu povo, a sétima casa no lado esquerdo da Ruela Verde, com um telhado velho e ermo e um segundo andar protuberante, tudo construído antes de 1650.

\footnotetext{
${ }^{1} \mathrm{~A}$ palavra arcaica foi escolhida para se referir às estrelas por conta de sua origem. Em grego antigo arkhé significa 'origem', 'aquilo que vem primeiro', 'unidade', por isso este prefixo também pode ser encontrado em palavras como arquivo, arqueologia e arcaísmo. Todas essas palavras estão diretamente ligadas ao conto e a este trabalho. As estrelas contam histórias sobre o passado, como um arquivo; o personagem descobre uma cidade antiga, como uma arqueóloga, e o texto, tanto em inglês quanto em português, é tecido com o auxílio de palavras pouco usadas - um arcaísmo literário.

${ }^{2}$ Para dar continuidade às influências mitológicas no conto, a palavra venusto - que vem da deusa Vênus - está presente no texto como forma de transcriar a atmosfera bela, atraente da deusa e de festival da cidade. Aos olhos de Lovecraft, um anglófilo incurável, todas as características europeias da cidade são atraentes, por isso transcríam-se suas proposições de tornar a cidade chamativa.
} 
Havia luzes dentro da casa quando me aproximei, pude ver pelas janelas losangulares de vidro que ela devia ter sido conservada como era em seu antigo estado. A parte superior projetava-se por sobre a estreita rua gramada e quase tocava na casa oposta, isso me fazia sentir como se estivesse em um túnel, sobre o baixo degrau da porta que estava completamente livre da neve. Não havia calçada, porém muitas das casas possuíam portas altas que precisavam de dois lances de escada e uma grade de ferro. Era uma cena singular, e como New England era exótica para mim, nunca vira nada igual. Apesar de me agradar, teria apreciado mais se tivessem pegadas na neve e pessoas nas ruas, e ao menos algumas janelas sem cortinas fechadas.

Quando golpeei a porta com a antiga aldrava de ferro me senti meio amedrontada. O medo estava se aglomerando dentro de mim, talvez influenciado pela excentricidade da minha herança, pela frigidez do anoitecer e pela estranheza daquela velha cidade de costumes curiosos. Quando meu chamado foi respondido me senti amedrontada por completo, pois não ouvira nenhum som de passos antes do ranger da porta que se abria. Mas o medo não durou muito, pois o velho de toga e sandálias tinha uma expressão serena que me tranquilizou, apesar de aparentar ser mouco, ele escreveu uma saudação excêntrica e antiga com seu estilete em sua tabuleta de cera.

Ele acenou para que eu entrasse em um cômodo baixo, à luz de velas, com enormes vigas expostas e com esparsa mobília escura e ríspida, que parecia ser do século XVII. O passado estava vívido ali, pois não faltava nenhum de seus atributos. Havia uma lareira críptica e uma roda de fiar sobre a qual se debruçava uma velha senhora trajando um chambre folgado e um gorro puritano. Ela estava de costas para mim e, apesar do período festivo, silenciosamente girava a roda. Uma vaga umidade pairava sobre o lugar, e me espantei ao perceber que nenhuma chama estava ardendo. A cadeira de encosto alto estava virada para as janelas acortinadas à esquerda, ela parecia estar ocupada, mas não tive certeza. Não gostei de todos os aspectos do que estava vendo, senti o medo de outrora surgir mais uma vez. O medo se tornava mais forte por aquilo que há pouco o abrandara, pois quanto mais eu observava a expressão serena no rosto do homem, ainda mais a própria serenidade me aterrorizava. Seus olhos não se moviam e sua derme era como cera. Por fim, tive a certeza de que aquilo não era sequer um rosto, mas uma máscara satanicamente ardilosa. Porém, suas mãos lânguidas, curiosamente enluvadas, escreveram cordialmente em sua tabuleta, me dizendo para esperar por alguns momentos antes de ser levada ao local do festival.

Apontando para uma cadeira, mesa e pilha de livros, o homem velho deixou o cômodo. Quando me sentei para ler, percebi que os livros eram muito antigos e bolorentos. Entre eles estavam o bárbaro Maravilhas da Ciência, do velho Morryster, o terrível Saducismus Triumphatus de Joseph Glanvill, publicado em 1681, o contundente Daemonolatria de Remigius, impresso em 1595 em Lyons, e o pior de todos, o inefável Necronomicon do árabe louco Abdul Alhazred, na tradução proibida para o latim de Olaus Wormius; um livro que jamais vira, mas sobre o qual ouvira por sussurros coisas monstruosas. Ninguém falou comigo, mas pude ouvir o 
ranger das tabuletas ao vento do lado de fora, e o chiar da roda enquanto a velha enchapelada continuava silenciosamente a fiar e fiar. Achei o cômodo, os livros e as pessoas muito mórbidas e inquietantes, mas devido à antiga tradição dos meus ancestrais que me invocaram para aquela pândega peculiar, resolvi esperar por coisas esquisitas. Então, tentei ler, e me tornei trepidamente sugada por algo que encontrei naquele amaldiçoado Necronomicon. Um mito e um pensamento hediondos demais para a sanidade ou para a consciência. Incomodei-me por crer ter ouvido o fechar de uma das janelas que se defrontava com a cadeira de encosto alto, como se ela tivesse sido ocultamente aberta. Esse som parecera seguir um chiado que não era aquele da roda de fiar da velha. Era um som pouco notável, pois a velha continuava a fiar severamente enquanto soavam as pancadas do relógio envelhecido. Depois disso a impressão de que alguém ocupava aquela cadeira se esvaiu, estava lendo com devoção e tremor quando o velho voltou, trajando botas e uma roupa antiga e folgada, sentou-se na cadeira de encosto alto e não pude mais vê-lo. $\mathrm{O}$ ato de esperar era indubitavelmente sôfrego, o livro blasfemo em minhas mãos tornava aquele sentimento ainda mais profundo. Contudo, quando as onze bateram, o velho se levantou, deslizou até um enorme baú entalhado que se encontrava em um canto, apanhou dois mantos encapuzados, pôs-se para dentro do primeiro e enroupou a velha com o segundo enquanto ela findava seu enfadonho fiar. Então os dois se encaminharam para a porta de saída, a senhora rastejava ao mancar e o velho, depois de pegar o livro que eu estava lendo, acenou-me à porta enquanto descia o capuz sobre aquele rosto ou máscara imóvel.

Nós saímos para o entrelaçamento desluarado e sinuoso daquela cidade incrivelmente antiga. Saímos enquanto as luzes das janelas acortinadas se dissipavam uma a uma. O Cão Maior olhava fulminante para a turba de figuras de manto e capuz que emanava silenciosamente de cada porta, formando uma procissão profana que se esgueirava por essa e por aquela rua, passando pelas tabuletas que rangiam, pelos antediluvianos telhados irregulares de palha e pelas janelas losangulares de vidro; galgando vielas íngremes onde casas putrescentes se sobrepunham e se esmigalhavam, deslizando sobre pátios abertos e adros onde a oscilação dos candeeiros formava ébrias constelações sobrenaturais.

Em meio a essa turba embatucada eu seguia meus guias taciturnos, empurrada por cotovelos que pareciam preternaturalmente moles, apertada por peitos e estômagos anormalmente hidrópicos. Porém sem nunca ver um rosto ou ouvir uma palavra sequer. Acima, sempre acima, o repulsivo pilar ascendia, e pude ver que todos os transeuntes estavam convergindo enquanto fluíam próximo a um medial de vielas tontas no topo da colina imponente no centro da cidade, onde encarrapitava-se uma grande igreja branca. Eu a vira da cimeira da estrada quando primeiro avistei Kingsport na escuridão recém-caída e ela me fez estremecer, pois Aldebaran pareceu ter se equilibrado por um momento em seu pináculo espectral.

Havia um espaço aberto ao redor da igreja, de um lado um adro com fustes fantasmagóricos, do outro uma praça meio pavimentada quase totalmente descoberta da neve que foi varrida pelo vento, delineada por vultuosas casas antigas de telhados ermos e empenados. 
Fogos-fátuos dançavam sobre as tumbas, revelando um cenário macabro, apesar de estranhamente falharem em lançar suas sombras. Ao passar pelo adro, onde não havia mais casas, pude ver por além da sumidade da colina o bruxuleio das estrelas sobre o ancoradouro, embora a cidade em si estivesse invisível nas trevas. Apenas de vez em quando um facho oscilava horrivelmente através das vielas sinuosas em seu caminho para alcançar a turba que agora escorregava silente para dentro da igreja. Esperei até que a multidão escoasse através da porta escura e até que todos os retardatários acompanhassem. O velho estava puxando minha manga, mas eu estava determinada a ser a última. Por fim, entrei, o homem aziago e a velha fiadeira diante de mim, cruzando a entrada até o templo pululando de escuridão desconhecida. Virei-me por um momento para ver o mundo exterior enquanto a fosforescência do adro lançava um brilho fraco sobre a sumidade pavimentada. Quando assim fiz, estremeci. Pois, apesar de o vento não ter deixado muita neve, restavam algumas porções no caminho próximo à porta; e naquele olhar de relance para trás pareceu aos meus olhos transtornados que ali não se encontravam marcas de pés transeuntes, nem ao menos dos meus.

A igreja estava escassamente iluminada por todos os candeeiros que a adentraram, pois a maioria da turba já havia desaparecido. Eles haviam escoado através do vão entre os bancos altos e brancos até o alçapão das abóbadas que bocejavam repugnantemente abertas diante do púlpito e agora estavam se contorcendo insonoros para dentro. Eu segui quietamente, descendo os degraus gastos para dentro da catacumba, mofada, fria e sufocante. A cauda daquela linha flexuosa de andarilhos noctâmbulos tinha uma aparência horrível, e quando a vi menear para dentro de um sepulcro venerável ela estava ainda mais horripilante. Então notei que o chão do sepulcro possuía uma fenda por onde a turba transcorria, e após um momento estávamos descendo uma escadaria ominosa de pedra rudimentar. Uma estreita escadaria em espiral, úmida e peculiarmente olorosa, que coleava sempiternamente para dentro dos intestinos da colina, passando por paredes contínuas de blocos de pedra gotejante e sedimento esmigalhado. Foi uma descida silenciosa e perturbadora, e percebi depois de um espantoso intervalo que as paredes e os degraus haviam mudado de consistência, como se talhados em rocha pura. A principal causa da minha aflição foi a falta de sons e ecos produzidos por aquela enxurrada de passos. Após mais evos de descida, avistei algumas vias laterais ou covas que eram expelidas do vácuo desconhecido de escuridão para esta cavidade de mistério obscuro. As cavidades logo se tornaram excessivamente numerosas, como ímpias sepulturas de ameaças inomináveis, seu odor pungente de podridão se tornava insuportável. Sabia que deveríamos ter passado por entre a montanha e por baixo do solo da própria Kingsport, me espantei por uma cidade ser tão primitiva e carunchosa com malignidade subterrânea.

Então pude ver o lúrido lucilar da lívida luz, e ouvir o embalo caviloso de águas sem sol. Mais uma vez senti arrepios, pois não gostava das coisas que a noite trouxera e desejava amargamente que meus antepassados não tivessem me invocado aqui para este ritual primevo. À medida que os degraus e a cavidade se tornavam mais largos ouvi outro som, o agudo 
lamuriar zombeteiro de uma fina flauta. De repente, se estendeu diante de mim uma ampla visão de um mundo oculto, uma vasta costa fúngica iluminada por uma regurgitada coluna de fraca chama esverdeada, banhada por um extenso rio oleoso que afluía de espantosos e insuspeitos abismos para se juntar às baías mais sombrias de um oceano imemorial.

Enfraquecida e ofegante, olhei para o profano érebo de cogumelos titânicos, fogo leproso e água viscosa. Vi a turba encapuzada formando um semicírculo ao redor de um pilar ardente. Era o Yule-rito, mais antigo do que a humanidade e destinado a sobrevivê-la, o ritual primevo do solstício e da promessa de primavera para além das neves, o ritual do fogo, do sempre-verde, da luz e da música. E naquela gruta estígia os vi realizar o ritual, idolatrando a pálida coluna de chamas, jogando para dentro da água escura punhados goivados da vegetação viscosa que tremeluzia verde sob o intenso brilho clorofílico. Vi isso e vi algo amorfo agachado longe da luz, sibilando fragorosamente em uma flauta; e enquanto a coisa sibilava eu pensei ter ouvido um maléfico flutuar abafado na escuridão fétida onde não podia enxergar. Mas o que me apavorou mais foi aquela coluna flamejante; jorrando vulcanicamente do âmago inconcebivelmente profundo, sem lançar sombra alguma como uma chama sã deveria, revestindo a pedra salitrosa acima com um azinhavre sórdido e virulento. Pois de toda aquela combustão fervilhante nenhum calor foi lançado, apenas a umidade da morte e da decomposição.

O homem que me trouxera contorceu-se até a um ponto diretamente ao lado da chama hedionda, fazendo moções cerimoniais rígidas em direção ao semicírculo. Em certos momentos do ritual eles faziam uma reverência rastejante, especialmente quando ele segurava sobre sua cabeça o repugnante Necronomicon que pegara de mim. Eu compartilhava todas as reverências porque havia sido invocada para este festival pelas escrituras dos meus ancestrais. Então o velho fez um sinal para a silhueta do tocador de flauta na escuridão, que em consequência mudou seu zumbido fraco para um zumbido um pouco mais alto, em outra nota, precipitando assim um horror impensável e inesperado. Nesse horror eu me afundei quase até sobre o líquen da terra, petrificada com o pavor que não poderia vir deste nem de qualquer outro mundo, mas apenas do vazio enlouquecedor entre as estrelas.

Saindo da escuridão inimaginável, além do brilho necroso daquela chama fria, dos alicerces tártaros pelos quais o rio oleoso corria inquieto, inaudível e insuspeito, lá esvoaçavam ritmicamente uma legião de coisas híbridas aladas, treinadas e domesticadas que nenhum olho são poderia compreender ou cérebro sadio relembrar inteiramente. Não eram exatamente corvos, nem toupeiras, nem abutres, nem formigas, nem morcegos vampiros, nem seres humanos em decomposição, mas algo que eu não posso, nem devo recordar. Eles se debatiam flacidamente pelo ar, parte com seus pés palmados e parte com suas asas membranosas. Enquanto alcançavam a turba de celebrantes, as figuras encapuzadas os agarravam e montavam, partindo um por um sobre o âmbito daquele rio desalumiado, para dentro de fossos e fendas de pânico onde fontes envenenadas alimentam horripilantes e ocultas cataratas. 
A velha fiandeira tinha partido com a turba, e o velho permaneceu apenas porque eu me recusei quando ele acenou para que eu agarrasse um animal e o cavalgasse como o resto. $\mathrm{Eu}$ vi, quando cambaleei em meus pés, que o tocador de flauta amorfo havia saído de vista, mas que duas das criaturas estavam esperando pacientemente. Quando hesitei o velho pegou seu estilete e a tabuleta de cera e escreveu que ele era o verdadeiro representante dos meus antepassados que haviam fundado a adoração a Yule neste lugar antigo, que fora decretado que eu deveria voltar, que os mistérios mais secretos ainda seriam realizados. Ele escreveu isso com uma letra muito antiga, e quando eu continuei a hesitar ele puxou do manto um anel com o selo e um relógio, ambos com o brasão da minha família, para provar que ele era quem dizia ser. Mas aquela era uma prova horrenda, porque eu sabia por velhos documentos que aquele era o relógio que havia sido enterrado com meu pentavô em 1698.

Logo o velho puxou seu capuz e apontou para as semelhanças familiares em seu rosto, eu apenas estremeci, eu tinha certeza de que aquele rosto não passava de uma máscara diabólica de cera. Os animais que estrebuchavam agora arranhavam agitadamente suas pústulas, percebi que o velho estava igualmente agitado. Quando uma das coisas começou a se mover para perto da beira, ele se virou rapidamente para impedi-la, de forma que o seu movimento súbito deslocou a máscara de cera daquilo que deveria ser sua cabeça. Então, porque a posição daquele pesadelo me barrava da escadaria de pedra da qual eu saíra, me arremessei naquele rio subterrâneo oleoso que borbulhava até alguma das cavernas do mar, me arremessei para dentro daquele suco putrescente dos horrores internos da terra antes que a loucura dos meus gritos pudesse atrair sobre mim todas as legiões cadavéricas que a baía pestilenta talvez escondesse.

No hospital eles me disseram que eu havia sido encontrada quase congelada no ancoradouro de Kingsport ao amanhecer, agarrada a um tronco à deriva que o acaso enviara para me salvar. Eles me disseram que eu peguei a encruzilhada errada na estrada pela colina na noite anterior e caí em um dos precipícios no Ponto Laranja, algo que deduziram pelas pegadas encontradas na neve. Não havia nada que eu pudesse dizer porque tudo estava errado. Tudo estava errado com a ampla janela mostrando um mar de telhados em que apenas um a cada cinco era antigo e o som do bondinho e de motores nas ruas abaixo. Eles insistiam que aquela era Kingsport e eu não poderia negar. Quando me tornei delirante ao ouvir que o hospital ficava perto do velho adro na Colina Central, eles me enviaram para o Hospital Santa Maria em Arkham, onde eu receberia melhores cuidados. Eu gostei de lá porque os médicos tinham a mente aberta, até me deixaram usar sua influência para conseguir a cópia cuidadosamente protegida do repreensível Necronomicon de Alhazred na biblioteca da Universidade Miskatônica. Eles disseram algo sobre "psicose" e concordaram que eu deveria me livrar de qualquer obsessão perturbadora.

Então eu li novamente aquele capítulo horrendo, e tremi intensamente porque ele não era novo para mim. Eu o vira antes, que as pegadas digam o que quiserem. O lugar onde eu o vira era melhor que fosse esquecido. Não havia ninguém, durante as horas lúcidas, que 
poderia me lembrar daquilo, mas meus sonhos estão cheios de pavor por conta de frases que não ouso citar. Atrevo-me a citar apenas um parágrafo, passado para o português do pouco que sei do grosseiro latim vulgar.

"As cavernas mais ínferas," escreveu o árabe louco, "não são para a compreensão dos olhos que podem ver; pois seus assombros são estranhos e aterrorizadores. Amaldiçoado seja o chão sobre o qual pensamentos mortos ganham nova vida e estranho corpo, e maligna a mente que não é contida por uma cabeça. Sabiamente disse Ibn Schacabao, bem-afortunado é o túmulo sobre o qual nenhum bruxo jamais repousou, e bem-afortunado o povoado à noite cujas bruxas são todas cinzas. Pois é um rumor antigo que as almas compradas pelo demônio fogem não de sua argila carnal, mas engordam e ordenam o próprio verme que as roam; até que da podridão brote vida repugnante, e os estólidos catadores de cera da terra a perturbem com astúcia e a inchem monstruosas para empestar. Enormes orifícios são escavados onde os poros da terra deveriam ser o bastante, e agora andam aqueles que deveriam apenas se arrastar."

\section{Cotejo}

O conto intitulado "The Festival" narra a história de um visitante da cidade de Kingsport que busca a casa de seus ancestrais para, junto a eles, realizar um antigo festival. O escritor, crítico literário e biógrafo de H.P. Lovecraft, Sunand Tryambak Joshi (2011) conta que Lovecraft provavelmente o escreveu em outubro de 1923. Sua suspeita é baseada na visita que o escritor fez à cidade de Marblehead, em Massachusetts, em dezembro do ano anterior. A cidade descrita no conto apresenta semelhanças pontuais com aquela visitada pelo autor. Além disso, a presença da bruxa e de seus rituais, de acordo com Joshi (2011), é resultado da influência do livro The Witch-Cult in Western Europe, escrito pela professora e arqueóloga inglesa Margaret A. Murray, lido por Lovecraft por volta de 1921. A tese apresentada pela professora Margaret Murray sobre rituais de adoração e sacrifícios para deuses antigos parece ter fascinado Lovecraft e tem importante influência também nesta tradução. No conto, a protagonista narra a história em primeira pessoa, o que, em língua inglesa, permite que seu gênero permaneça neutro. Uma tradução para o português focada em neutralizar a linguagem do texto seria uma tarefa árdua e artisticamente infrutífera. Escolhemos "transcriar" o personagem com o gênero feminino. Os motivos para essa escolha são: a influência do livro de Murray para o autor, maior presença da mulher na literatura de horror ao longo do século XX e a evidente ascensão - mesmo que ainda timidamente valorizada - da literatura e circulação de textos de autoria feminina no século XXI.

Na referida obra de Murray (2001), são encontradas descrições dos diferentes rituais macabros que eram supostamente praticados pelas bruxas europeias. Na maioria dos rituais, 
eram as mulheres que iniciavam o contato com a entidade divina. Nos rituais de admissão, em específico, ainda com a arqueóloga, o contato com a divindade era quase exclusividade das mulheres. Sobre isso, Murray afirma: "a cerimônia pode acontecer em lugar privado, uma reunião local, ou em um sabá ${ }^{3}$ completo; era a mesma independente do sexo, porém os homens não eram comumente introduzidos [...]"4 (MURRAY, 2001, p. 44, tradução nossa). Além disso, a pesquisadora Ruth Whitehouse (2013), em seu artigo sobre Margaret Murray, aponta que a professora, arqueóloga e egiptóloga, foi, também, uma feminista praticante. Segundo a pesquisadora, a professora Murray fez parte do Women's Social and Political Union e esteve presente nos protestos em favor da expansão dos direitos políticos femininos na Inglaterra em 1907. A Whitehouse (2013) também destaca que os livros sobre bruxarias da professora influenciaram a fundação de movimentos neopagãos como o Wicca.

Em seu artigo sobre a literatura gótica no século XX, a escritora Ruth Benander (2013) explica parte da trajetória da mulher como personagem nas histórias góticas. A escritora destaca que nas primeiras histórias do gênero as mulheres eram tidas como acessório narrativo, porém a mudança do papel da mulher na sociedade causou repercussões também na Literatura gótica. Outra justificativa apresentada por Benander (2013) é o crescimento do público feminino consumidor de ficção desse gênero. Portanto, há a necessidade de identificação desse público com os personagens da história. Tal necessidade, acreditamos, é aumentada em uma história narrada em primeira pessoa, como em "The Festival", que precisa que o(a) leitor(a) se projete na narrativa para que esta alcance o efeito pretendido.

Como exposto por Joshi (2001), Lovecraft teve grandes inspirações a partir da literatura gótica, especialmente de Edgar Allan Poe, autor que retratava as mulheres de maneira trágica. Por conta da presença e influência de Murray e Poe no conto "The Festival" e de toda a carga histórica e social que o acompanha, a opção na transcriação da narrativa foi o de selecionar o gênero da protagonista como o feminino.

Dessa forma, todos os gêneros neutros foram direcionados à pessoa de uma mulher, cujas informações a esse respeito são dadas e apresentadas de modo paulatino, assim como as características do ambiente do conto. O passado da personagem principal só é mencionado quando indispensável para o desenvolvimento da história. A narrativa está ambientada em um espaço geográfico único e peculiar: a cidade de Kingsport. A protagonista não vê a gigantesca montanha que atinge os céus, escondendo algumas estrelas. A cidade é bem detalhada na narrativa, a ponto de ser descrita ao leitor como suas ruas tortas se assemelham a labirintos, como suas casas estão confusamente dispostas e como as luzes das janelas se misturam às estrelas no horizonte. A atmosfera sombria presente no lugar é minuciosamente construída

\footnotetext{
${ }^{3}$ Sabbath é uma cerimônia religiosa que envolve todos os indivíduos praticantes da crença que habitam a região em que a reunião ocorre.

${ }_{4}^{4}$ "The ceremony might take place privately, at a local meeting, or in full Sabbath; it was the same for either sex, except that the men were not usually introduced" (MURRAY, 2001, p. 44).
} 
por Lovecraft, isto é, a cidade é apresentada como um personagem vivo, uma criatura monstruosa. A protagonista anda por sua pele, depois desce as escadarias secretas da igreja como se elas fossem a garganta da besta e, por fim, se joga na água escura e gelada, sendo expelida de seu interior e acordando em um lugar completamente diferente, apesar de parecer o mesmo.

A característica sensitiva principal em quase toda obra de Lovecraft é o medo. Para o autor, "a mais forte e antiga emoção humana é o medo, e o mais forte e antigo tipo de medo é o medo do desconhecido"s (LOVECRAFT, 2011, p. 1041, tradução nossa). No conto, a protagonista não chega a presenciar o verdadeiro ritual, o horror instituído pelas descrições de Lovecraft ao longo do caminho a força a desistir para que não enlouqueça.

Em seu livro A teoria estética, o filósofo alemão Theodor Adorno (2013) explica que, dentro da teia enigmática da obra de arte verbal, o autor está emaranhado em sua obra, mesmo que esta não seja a sua intenção. Isso ocorre no trabalho de Lovecraft traduzido aqui. No conto, a anglofilia do escritor transparece no nome e na arquitetura da cidade de Kingsport e na busca do protagonista por suas raízes ancestrais. Seu fascínio pela antiguidade grega é visto principalmente nas imagens criadas no texto, como a cidade que aparenta ser um labirinto e a caverna sombria que parece levar ao Hades. O pai do autor, Winfield Lovecraft, é mimetizado no final do conto do mesmo modo que representava para si, na infância: uma pessoa insana, vivendo presa em um hospício. Outra memória infantil do autor que está presente no texto está expressa nas descarnadas-noturnas, criaturas aladas e malignas com as quais ele tinha pesadelos quando criança. Acresce-se aí, o terrível medo do escuro que tinha e que fora relatado por Joshi (2001), seu biógrafo.

No aspecto tradutório, Walter Benjamin alerta que afinidade entre línguas não corresponde a semelhança. Deve-se pensar nas línguas despidas de seu parentesco histórico e linguístico, pois essa intimidade se apresenta mais fortemente no fato de que todos os signos verbais de uma língua significam algo. A esse respeito, Benjamin afirma que: "[...] enquanto todos os elementos singulares, as palavras, as frases, as correlações de línguas estrangeiras se excluem, essas línguas se complementam em suas próprias intenções" (BENJAMIN, 2008, p. 56). Essa intenção de significar reside no que o filósofo alemão chama de modo de significar, que, na verdade, é algo além do significado, é a intenção da obra, são os motivos, conscientes ou não, que levaram à escolha de cada palavra que compõe o texto. Assim, em um texto escrito em língua inglesa, o autor pode fazer uso de uma palavra de origem latina com o propósito de significar algo antigo, de pouco uso. Ao traduzir para o português brasileiro, o tradutor-autor pode se sentir tentado a usar um cognato, visto que a língua de chegada é latina. Contudo, nesse processo, a intenção do texto originário seria perdida. Por exemplo: em "The Festival", H.P. Lovecraft escreve: "endless labyrinths of steep, narrow, crooked streets" (LOVECRAFT, 2011, p.

\footnotetext{
5"The oldest and strongest emotion of mankind is fear, and the oldest and strongest kind of fear is fear of the unknown" (LOVECRAFT, 2011, p. 1041).
} 
262) para ambientar a cidade onde o conto se passa. O tradutor poderia escrever, por exemplo, "labirintos infindos de ruas tortas, estreitas e íngremes". No entanto, o modo de significar seria perdido, pois a palavra labirinto é comumente usada no português brasileiro, ao passo que labyrinth sequer aparece na lista das cinco mil palavras mais usadas da língua inglesa, contida no website Word Frequency Data (2016). Na tradução contida neste trabalho foi escolhida a palavra "dédalo" como forma de transcriação do modo de significar de labyrinth porque, além de preservar longinquamente o infortúnio de Minotauro, ela resguarda o propósito de parecer antigo, pouco usado. Esta escolha desafia o leitor a buscar os possíveis significados de "dédalo" e contribui para a construção da atmosfera misteriosa e antiga do conto em sua versão de partida. A personagem central da história irá perder-se na cidade em que está entrando, assim como Dédalo ${ }^{6}$ o personagem da mitologia grega de onde a palavra se origina - se perde em Creta, seu labirinto. Da mesma forma, no final do conto, a personagem poderá fugir dali com o auxílio de asas. Como resultado, são "transcriadas" a proposta inicial, a atmosfera e as influências literárias de Lovecraft. Se, neste caso específico, ele fez uso de termos antigos e poucos usuais para criar a sua narrativa, é salutar que transcriemos também esse conjunto identitário do autor. Se, para Benjamin, a tarefa do tradutor "consiste em encontrar, na língua para a qual se traduz, aquela intenção da qual é nela despertado o eco do original" (BENJAMIN, 2008, p. 59), para Campos, a "tradução de textos criativos será sempre recriação, ou criação paralela, autônoma porém recíproca. Quanto mais inçado de dificuldades esse texto, mais recriável, mais sedutor enquanto possibilidade aberta de recriação". E completa: "Numa tradução dessa natureza, não se traduz apenas o significado, traduz-se o próprio signo, ou seja, sua fisicalidade, sua materialidade mesma" (CAMPOS, 2015a, p. 5, grifo do autor).

Durante o processo, a transcriação se mostrou adequada enquanto ferramenta utilizada para verter a massa de significados do inglês para o português, permitindo recriar características detalhadas presentes no conto, na prática e na biografia de Lovecraft. Desde a presença de aliterações que surgem nas longas sequências descritivas ("longínquas lendas prevalecem em lugares solitários" para "village legend lives long", $6^{\circ}$ parágrafo; "lúrido lucilar da lívida luz", "lurid shimmering of pale light", $15^{\circ}$ parágrafo), à temática contida na seleção das palavras (criação do termo "desluarado" como solução para "moonless", $11^{\circ}$ parágrafo). Foram encontradas algumas particularidades e dificuldades na tradução do conto. Dentre elas, a questão da pontuação foi um dos elementos responsáveis por muita reflexão. Lovecraft utiliza o ponto e vírgula de maneira aparentemente irregular, o que gera uma quebra no ritmo do texto. O crítico literário Roger Luckhurst (2013) afirma que Lovecraft não utiliza a pontuação de maneira irrefletida. Pelo contrário, o uso do ponto e vírgula fora do padrão tem a função de causar estranheza no leitor não apenas por meio da narrativa em si e das palavras pouco

\footnotetext{
${ }^{6} \mathrm{O}$ livro consultado sobre a mitologia grega para escrever este comentário foi O Livro de Ouro da Mitologia Grega, de Thomas Bulfinch (1965). De acordo com S.T. Joshi (2001), biógrafo de Lovecraft, este mesmo livro foi usado pelo escritor como fonte de consulta.
} 
conhecidas, mas que tal assombro também estivesse presente na menor unidade do texto. Do mesmo modo, o autor faz bastante uso de repetições de substantivos e de excessivo uso de adjetivos e advérbios para marcar a atmosfera de horror do conto. Essa estratégia criativa também presente em outras obras de Lovecraft - algumas vezes mimetiza um mantra de bruxo que precisa deixar patente, via diversos elementos comunicativos, a mensagem pretendida.

$\mathrm{Na}$ transcriação do conto, optamos por manter a repetição deliberada de termos, bem como o ponto e vírgula nos momentos de extensa descrição, como visto em todo o terceiro parágrafo, e substituí-lo por vírgulas - igualmente descolocadas/fora do padrão - nos demais momentos. Foi o modo que selecionamos para traduzir "o próprio signo" das unidades básicas do conto.

Ainda como particularidades, há a citação em latim no início do conto, que poderia ser traduzida para a língua portuguesa com a seguinte frase: "Os demônios se fazem parecer por aquilo que não são, como se verdadeiramente fossem, para capturar os homens que se arriscam". Preferimos não a traduzir com o intuito de realçar sua atmosfera misteriosa e velada. A frase faria parte da obscuridade da obra ou, para usar a expressão adorniana, do enigma da obra de arte. Assim, caberia à leitora buscar decifrá-lo.

No primeiro parágrafo, Lovecraft estabelece que a cidade para a qual a viajante caminha é antiga, o autor a caracteriza com a palavra old. Essa palavra poderia ser traduzida com o termo velho, todavia, o vocábulo escolhido para transcriar a principal característica da cidade foi macróbio. Por ser uma palavra pouco usada no cotidiano (portanto, assente ao que apresenta o texto de partida), causa na leitora/leitor a impressão de encontrar em um texto antigo uma palavra que tenha caído em desuso, exatamente uma das sensações que o texto estimula na recepção. A origem da palavra macróbio também tem ligação com o texto, vem do filósofo romano Macrobius Ambrosius Theodosius. De acordo com Alan Cameron (1966), o Macrobius viveu no século IV d.C. e escreveu a Convivia primi diei Saturnaliorum e o Commentarium in Ciceronis Somnium Scipionis. O primeiro livro descreve um banquete filosófico no qual são discutidas principalmente as adorações pagãs ao deus Saturno. No segundo, é narrado um sonho de Cipião Emiliano em que ele se eleva aos céus e ouve de seus antepassados a explicação do funcionamento do Cosmos. É possível traçar um paralelo entre a narrativa de "The Festival" e as dos livros de Macrobius. Assim como no primeiro livro citado, a história do conto também trata de um ritual pagão que foi assimilado pelo cristianismo, o Yuletide. E, da mesma forma como Cipião interpreta as estrelas em seu sonho, Lovecraft trata a astronomia como o caminho para o desconhecido, para aquilo que está além da compreensão humana.

Por fim, uma das bases do processo tradutório da transcriação é a transposição do campo de referências. Em sua obra em inglês, Lovecraft referencia autores como Margaret Murray e Lord Dunsany. Na versão transcriada por nós para a língua portuguesa, o autor que selecionamos para atividade foi Augusto dos Anjos. Esta escolha se construiu por meio das semelhanças históricas e temáticas entre os autores de língua inglesa e o de língua portuguesa. 
Em nossa transcriação, tanto o termo "hidrópicos", no $12^{\circ}$ parágrafo, quanto a frase "os vermes róem", no último parágrafo, são uma tentativa de inserir no conto o primeiro terceto do poema O Deus-verme de Augusto dos Anjos: "Almoça a podridão das drupas agras, / Janta hidrópicos, rói vísceras magras/ E dos defuntos novos incha a mão...” (ANJOS, 1998, p. 7).

\section{Considerações finaIS}

A transcriação foi idealizada para tentar resolver as questões das traduções de versos ou de prosas que apresentem "labirintos" vistos com maior incidência na poesia. Contudo, mesmo que não esteja inscrito no gênero "poesia", o conto de Lovecraft possui diversos aspectos poéticos em sua construção, de modo que os esforços desenvolvidos por Haroldo de Campos em seu processo tradutório nos serviram como uma possibilidade bastante viável para a solução dos obstáculos enfrentados nesta leitura crítica. Houve, com isso, a pretensão de experimentarmos quanto esse percurso pode ser aplicado a contos de horror e como ele pode ser um ponto de partida ou de chegada a trabalhos que lidem com esses autores da literatura universal: Lovecraft e Campos.

\section{REFERÊNCIAS}

ADORNO, Theodor. Teoria estética. Tradução de Artur Morão. $1^{a}$ reimpr. 2. ed. Lisboa: Edições $70,2013$.

ANJOS, Augusto dos. Eu e outras poesias. 42. ed. Rio de Janeiro: Civilização Brasileira, 1998. BENANDER, Ruth. Gothic Genre: A 2oth Century Gothic Story Expressing Fear, forbidden love, and the Evolution of Women Characters. 2013. Lynseynguyen. Disponível em: https:// lynseynguyen.wordpress.com/short-essays/gothic-genre-a-2oth-century-gothic-storyexpressing-fear-forbidden-love-and-the-evolution-of-women-characters/. Acesso em: 7 ago. 2016.

BENJAMIN, Walter. A Tarefa do Tradutor. In: BRANCO, Lúcia C. (Org.). A Tarefa do Tradutor, de Walter Benjamin: quatro traduções para o português. Belo Horizonte: UFMG, 2008. p. 56-64. BULFINCH, Thomas. O Livro de Ouro da Mitologia Grega: Histórias de deuses e heróis. Tradução de David Jardim Júnior. Rio de Janeiro: Tecnoprint, 1965.

CAMERON, Alan. The Date and Identity of Macrobius. The Journal of Roman Studies, London, V. 56, p. 25-38, 1966.

CAMPOS, Haroldo de. Da Tradução Como Criação e Como Crítica. In: TÁPIA, Marcelo; NOBREGA, Thelma M. (Org.). Haroldo de Campos: Transcriação. São Paulo: Perspectiva, 2015a. p. 1-18. 
CAMPOS, Haroldo de. Tradução e Reconfiguração: O tradutor como transfingidor. In: TÁPIA, Marcelo; NOBREGA, Thelma M. (Org.). Haroldo de Campos: Transcriação. São Paulo: Perspectiva, 2015b. p. 109-130.

CAMPOS, Haroldo de. Tradução, ideologia e história. In: TÁPIA, Marcelo; NOBREGA, Thelma M. (Org.). Haroldo de Campos: Transcriação. São Paulo: Perspectiva, 2015c. p. 37-46.

CAMPOS, Haroldo de. Da Transcriação: poética e semiótica da operação tradutora. In: TÁPIA, Marcelo; NOBREGA, Thelma M. (org.). Haroldo de Campos: Transcriação. São Paulo: Perspectiva, 2015d. p. 77-104.

GESSNER, Ricardo. Transcriação, Transconceituação e poesia. Cad. Trad., Florianópolis, v. 36, n. 2, p. 142-162, 2016.

JAKOBSON, R. Lingüística e Comunicação. São Paulo: Cultrix, 1975.

JONES, Steven P. The Worlds of H.P. Lovecraft: The Picture in the House. Michigan: Caliber Comics, 2014.

JOSHI, S. T. A Dreamer and a Visionary: Lovecraft in his time. Liverpool: Liverpool University Press, 2001.

JOSHI, S. T. Introduction. In: LOVECRAFT, H.P. H.P. Lovecraft: The Complete Fiction. Nova York: Barnes and Noble, 2011, p. 9-14.

LOVECRAFT, H.P. H.P. Lovecraft: The Complete Fiction. Nova York: Barnes and Noble, 2011. LUCKHURST, Roger. Introduction. In: LOVECRAFT, H. P. The Classic Horror Stories. Oxford: Oxford University Press, 2013, p. 11-13.

MAGALHÃES, Célia. Tradução e Transculturação: A teoria monstruosa de Haroldo de Campos. Cadernos de Tradução UFSC, Florianópolis, v. 3, p. 139-156, 1998.

MURRAY, Margaret Alice. The Witch Cult in Western-Europe. Oxford: Claredon Press, 2001. POUND, Ezra. Literary Essays. Nova York: New Directions Publishing, 1968.

RÓNAI, Paulo. Escola de Tradutores. Rio de Janeiro: Livraria São José, 1976.

SOUZA, José Pinheiro. Teorias da Tradução: Uma visão integrada. Rev. de Letras, São Paulo, v. 1-2, n. 20, p. 51-67, 1998.

TÁPIA, Marcelo. Posfácio: o eco antropofágico. In: TÁPIA, Marcelo; NOBREGA, Thelma M. (Org.). Haroldo de Campos: Transcriação. São Paulo: Editora Perspectiva, 2015. p. 215-232.

WHITEHOUSE, Ruth. Margaret Murray (1863-1963): Pioneer Egyptologist, Feminist and First Female Archaeology Lecturer. 2013. Archaeology International. Disponível em: http://www. ai-journal.com/articles/10.5334/ai.1608/. Acesso em: 7 ago. 2016. 
WORD FREQUENCY DATA. Corpus of Contemporary American English. Disponível em: http://www.wordfrequency.info/free.asp?s=y. Acesso em: 15 jul. 2016.

Recebido para publicação em: 1 jun. 2020. Aceito para publicação em: 11 dez. 2020. 